\title{
Changes in production of organic nitrogen and carboxylates (C-A) in young sugar-beet plants grown in nutrient solutions of different nitrogen composition
}

\author{
V. J. G. Houba, F. van Egmond and E. M. Wittich \\ Department of Soils and Fertilizers, Agricultural University, Wageningen, \\ the Netherlands
}

Received: 20 October 1970

\section{Summary}

Sugar-beet plants were grown in a growth chamber in culture solutions with nitrate. After 19 days the plants were transferred to culture solutions with nitrate, or with ammonium or without nitrogen. The production of carboxylates in the plants was compared with the production of organic nitrogen.

The results expressed in equivalents can be summarized as follows:

$\mathrm{NO}_{3}$ plants : $\mathrm{C}-\mathrm{A}=$ organic $\mathrm{N}$

zero-N plants : $\mathrm{C}-\mathrm{A}>$ organic $\mathrm{N}$

$\mathrm{NH}_{4}$ plants : $\mathrm{C}-\mathrm{A}<$ organic $\mathrm{N}$

These differences are accompanied by a small increase in $\mathrm{pH}$ of the culture solution of nitrate plants and a sharp decrease in $\mathrm{pH}$ in the other treatments.

\section{Introduction}

Differences in the uptake between inorganic cations and inorganic anions are accompanied by changes in the amount of carboxylates present in plants tissues (Ulrich, 1942). The metabolic conversion of nitrates and sulphates into non-ionic organic $N$ and $S$ gives rise to an equivalent quantity of carboxylates in plant tissues (Dijkshoorn, 1962). Table 1 summarizes the processes which influence the carboxylate pool. When there is a substantial uptake of ions other than those mentioned in Table 1, such ions, for instance $\mathrm{NH}_{4}+$, should also be considered.

Since sulphate reduction is small compared with nitrate reduction the former will be neglected in the present discussion. Dijkshoorn et al. (1968) in experiments with perennial rye-grass (Lolium perenne L.), grown in nutrient solution, assumed that their results could be explained by Processes 1, 3 and 4 mentioned in Table 1. Van Egmond and Houba (1970), working with sugar-beet (Beta vulgaris L.) on complete nutrient solution, could explain their results with Processes 3 and 4 only. Process 1 does not take place in sugar-beet plants, or it was so small that it could not be demonstrated (van Egmond and Houba, 1970).

Houba (unpublished results) using data from field experiments with sugar-beet concluded that the excess of inorganic cations over inorganic anions was higher than the amount of organic nitrogen in the whole plant as soon as nitrate was depleted. This 
Table 1. Processes which influence the carboxylate pool.

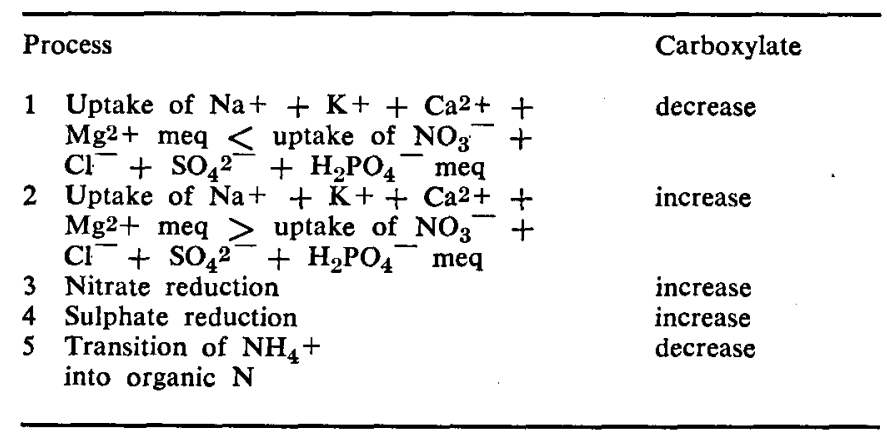

points to the possibility of introducing Process 2, by replacing nitrate in the nutrient solution by chloride or sulphate. Dijkshoorn et al. (1968) used this procedure to demonstrate Process 2 in Lolium perenne. If nitrate is replaced by ammonium as the source of nitrogen, Process 2 (increase in carboxylate production) is followed by Process 5 (decrease in carboxylate production). Only the net change in amount of carboxylates can be determined. Dijkshoorn et al. (1968) working with rye-grass showed that with ammonium chloride as nitrogen source (and no potassium), the organic nitrogen increased rapidly but the carboxylate production stopped.

The aim of the trial described in this article was to investigate if there is any further production of carboxylates in young sugar-beet plants when the nitrate reduction is stopped due to nitrate depletion brought about by either substitution of ammonium for nitrate, or by omission of nitrogen in the supplied salts.

\section{Experimental}

Diploid sugar-beet seeds (No P 2167) were sown in sand. After germination the seedlings were placed on a well-aerated nutrient solution. The composition of the nutrient

Table 2. Composition of the nutrient solutions.

\begin{tabular}{|c|c|c|c|}
\hline \multirow[t]{2}{*}{ Component } & \multicolumn{3}{|c|}{ Concentration in meq $/ 1$} \\
\hline & $\underset{\text { (a) }}{+\mathrm{NO}_{3}}$ & $\begin{array}{l}\text { zero-N } \\
\text { (b) }\end{array}$ & $\begin{array}{l}+\mathrm{NH}_{4} \\
\text { (c) }\end{array}$ \\
\hline $\mathrm{Na}$ & 2 & 2 & 1 \\
\hline $\mathbf{K}$ & 4 & 3 & 2 \\
\hline $\mathrm{Ca}$ & 2.5 & 2.5 & 1.25 \\
\hline $\mathrm{Mg}$ & 4 & 3 & 2 \\
\hline $\mathrm{NH}_{4}$ & - & - & 4 \\
\hline $\mathrm{H}_{2} \mathrm{PO}_{4}$ & 1 & 1 & 1 \\
\hline $\mathrm{NO}_{3}$ & 6 & - & - \\
\hline $\mathrm{Cl}$ & 3 & 3 & 3 \\
\hline $\mathrm{SO}_{4}$ & 2.5 & 6.5 & 6.25 \\
\hline
\end{tabular}

Trace elements according to Hoagland, Fe-EDTA $35 \mathrm{mg} / \mathrm{l}$. 

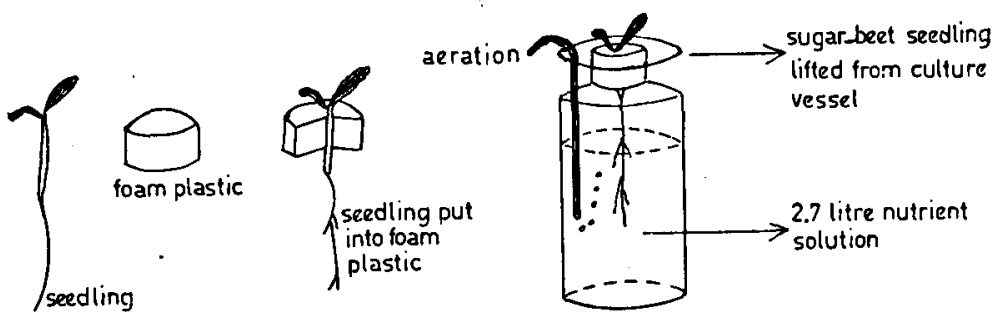

Fig. 1. Growing sugar-beet on a nutrient solution.

solution is given in Table 2a. Fig. 1 shows how the plants were held in foam plastic.

The nutrient solutions were renewed at regular intervals in order to avoid possible nutrient shortages. The trial was carried out in a growth chamber. The daily light period was 14 hours, while the temperature was $25^{\circ} \mathrm{C}$ during the light period and $17^{\circ} \mathrm{C}$ during the dark period; the relative humidity was 80 to $90 \%$. After 19 days of growth on the culture solution with nitrate (Table 2a), 10 plants were kept on the nitrate solution (Table 2a), 18 were transferred to a solution without nitrogen (Table $2 \mathrm{~b}$ ) and 12 were transferred to an ammonium solution (Table $2 \mathrm{c}$ ).

Plants were harvested after 19, 23, 30, 33 and 36 days from the day of transplanting from the seed bed, and divided into three sections: leaf blades (including the midribs), petioles and beet + roots. For each section, the fresh and dry weights were recorded and the material was finely ground and analysed as described by van Egmond and Houba (1970). The carboxylates were extracted using water in the presence of a $\mathrm{H}^{+}$sulphonic acid resin. Since this treatment did not extract all the oxalates, the remaining oxalates were determined oxidimetrically with $\mathrm{KMnO}_{4}$ following a double treatment of the samples with $2 \mathrm{~N} \mathrm{HCl}$. (In the blank determination hardly any $\mathrm{KMnO}_{4}$ was used.) The $\mathrm{pH}$ of the nutrient solutions was measured regularly from the 19th day until the 33 th day of the trial.

\section{$G$ Results and discussion}

\section{Dry-matter production}

Dry weights and contents are tabulated in Table 3.

At the end of the experiment the dry-matter production of the nitrate plants was higher than that of the plants from the other solutions. The dry-matter production of the ammonium plants fell behind that of the nitrate plants only during the last three days of the trial. The lowest dry-matter production during the whole period was obtained with plants lacking nitrogen in the culture solutions. The distribution of the produced dry matter over the various plant parts is given in Table 4 . Without nitrate in the culture solution, the dry matter produced is located for a larger part in the roots.

\section{The balance of uptake and utilization of inorganic ions}

Plants with nitrate. Van Egmond and Houba (1970) already described the balance of uptake and utilization of inorganic ions by sugar-beet plants grown on a culture solu- 
v. J. G. HOUBA, F. VAN EGMOND AND E. M. WITTICH

Table 3. Content of cations, anions and organic substances of the sugar-beet plants in meq/ $\mathrm{kg}$ dry matter

\begin{tabular}{lllllllllll}
\hline $\begin{array}{l}\text { Days after } \\
\text { transplanting }\end{array}$ & $\begin{array}{l}\text { Treat- } \\
\text { ment }\end{array}$ & $\begin{array}{l}\text { Dry weight } \\
\text { (g/3 plants) }\end{array}$ & $\mathrm{Ca}$ & $\mathrm{Na}$ & $\mathrm{K}$ & $\mathrm{Mg}$ & $\mathrm{C}$ & $\mathrm{H}_{2} \mathrm{PO}_{4}$ & $\mathrm{NO}_{3}$ & $\mathrm{Cl}$
\end{tabular}

\section{Leaf blade}

$\begin{array}{llr}19 & +\mathrm{NO}_{3} & 6.6 \\ 23 & +\mathrm{NO}_{3} & 7.8 \\ 30 & +\mathrm{NO}_{3} & 13.8 \\ 33 & +\mathrm{NO}_{3} & 19.4 \\ 36 & +\mathrm{NO}_{3} & 31 . \\ & & \\ 23 & \text { zero-N } & 7.0 \\ 30 & \text { zero-N } & 10.4 \\ 33 & \text { zero-N } & 10.5 \\ 36 & \text { zero-N } & 11.9 \\ & & \\ 23 & +\mathrm{NH}_{4} & 7.2 \\ 30 & +\mathrm{NH}_{4} & 14.3 \\ 33 & +\mathrm{NH}_{4} & 14.4 \\ 36 & +\mathrm{NH}_{4} & 17 .\end{array}$

$\begin{array}{rrrrrrrr}416 & 371 & 2250 & 1220 & 4257 & 246 & 410 & 98 \\ 470 & 466 & 2045 & 1386 & 4367 & 319 & 480 & 79 \\ 380 & 441 & 1940 & 1664 & 4425 & 237 & 490 & 129 \\ 450 & 498 & 2120 & 1620 & 4688 & 217 & 703 & 203 \\ 380 & 375 & 1853 & 1702 & 4310 & 199 & 630 & 129 \\ & & & & & & & \\ 456 & 408 & 1850 & 1184 & 3898 & 605 & 65 & 143 \\ 420 & 320 & 1603 & 1076 & 3419 & 854 & 29 & 49 \\ 546 & 366 & 1490 & 1314 & 3716 & 835 & 29 & 53 \\ 642 & 425 & 1253 & 1348 & 3668 & 1080 & 29 & 86 \\ 394 & 378 & 1700 & 1162 & 3634 & 808 & 130 & 87 \\ 312 & 424 & 1370 & 984 & 3090 & 1015 & 94 & 80 \\ 372 & 388 & 1210 & 1020 & 2990 & 1270 & 55 & 51 \\ 382 & 474 & 929 & 1214 & 2999 & 1380 & 32 & 84\end{array}$

Petiole

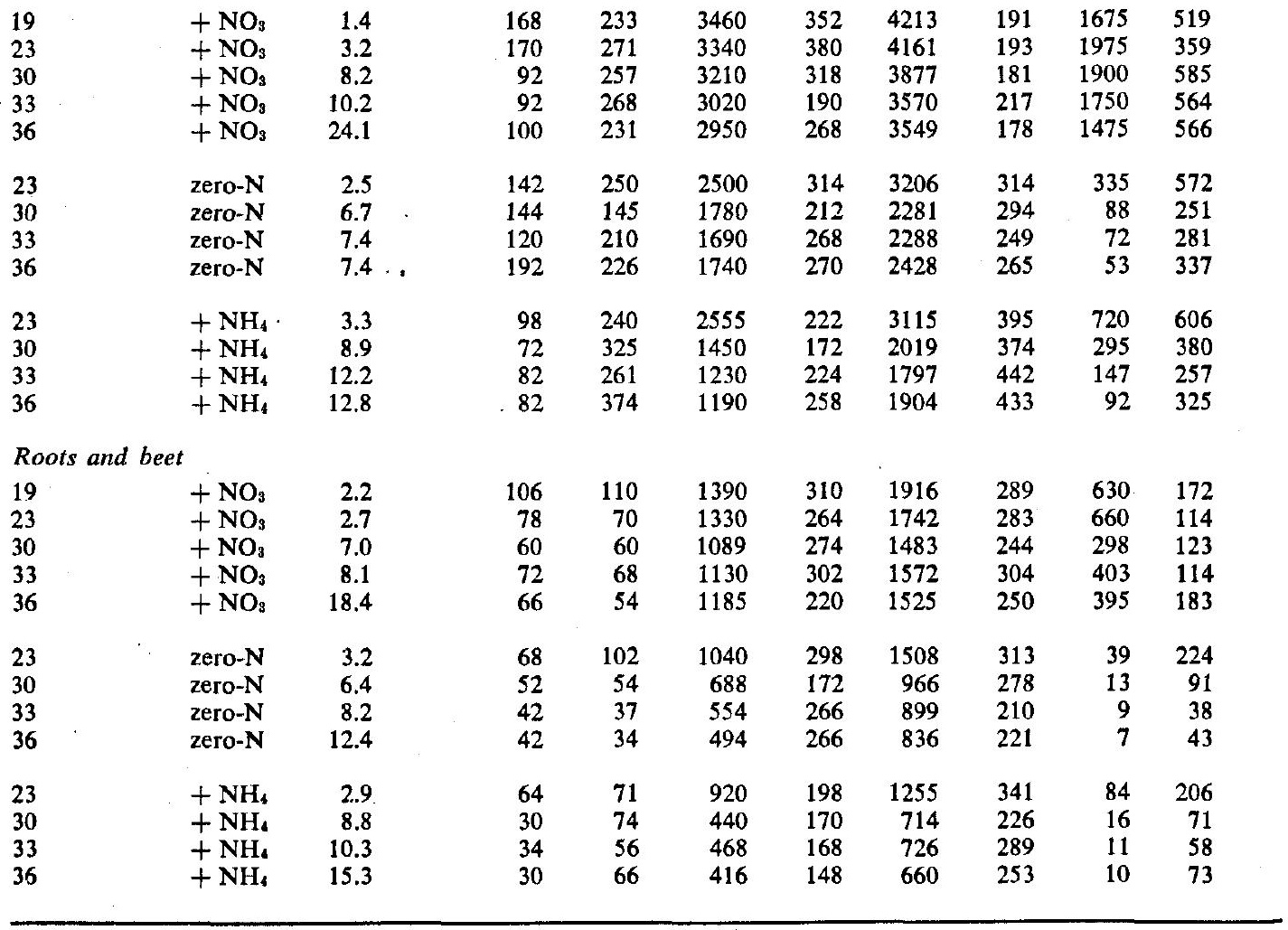

$-=$ not determined.

$\bar{I}=$ citric acid; II = malic acid; III = oxalic acid;

IV = succinic and malonic acid? (traces); V = fumaric acid? (traces). 
(total $\mathrm{N}$ and organic $\mathrm{N}$ in mmole/ $\mathrm{kg}$ dry matter).

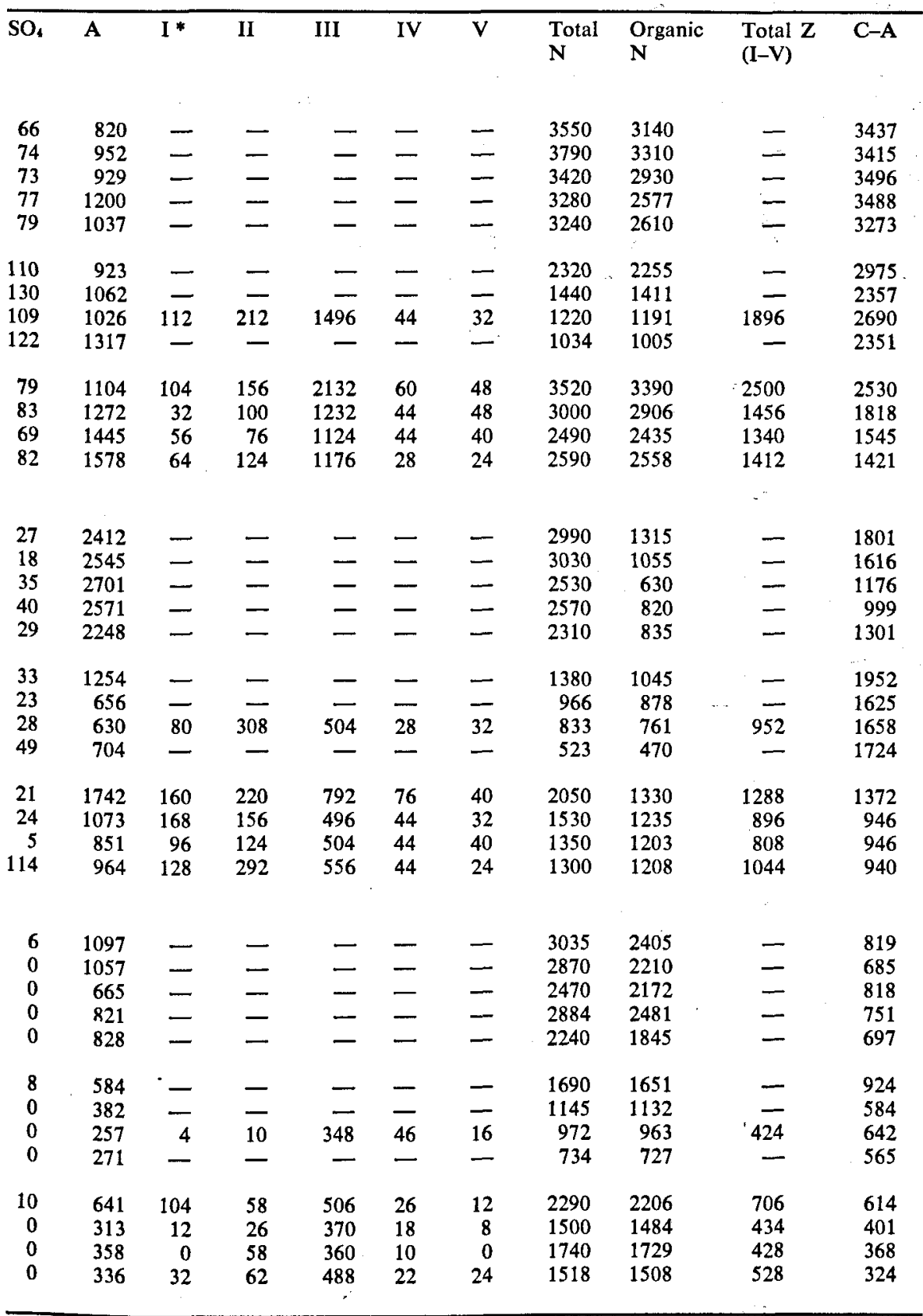


Table 4. Distribution in $\%$ of the produced dry matter over the shoots and roots of sugar-beet plants grown with nitrate, with ammonium or without nitrogen in the culture solution.

\begin{tabular}{|c|c|c|c|c|c|c|}
\hline \multirow{2}{*}{$\begin{array}{l}\text { Days after } \\
\text { transplanting }\end{array}$} & \multicolumn{3}{|l|}{ Shoot } & \multicolumn{3}{|l|}{ Root } \\
\hline & $+\mathrm{NO}_{3}$ & zero-N & $+\mathrm{NH}_{4}$ & $+\mathrm{NO}_{3}$ & zero-N & $+\mathrm{NH}_{4}$ \\
\hline $\begin{array}{l}19 \\
23 \\
30 \\
33 \\
36\end{array}$ & $\begin{array}{l}79 \\
80 \\
76 \\
78 \\
75\end{array}$ & $\begin{array}{l}\overline{75} \\
72 \\
68 \\
61\end{array}$ & $\begin{array}{l}\overline{78} \\
73 \\
72 \\
66\end{array}$ & $\begin{array}{l}21 \\
20 \\
24 \\
22 \\
25\end{array}$ & $\begin{array}{l}\overline{25} \\
28 \\
32 \\
39\end{array}$ & $\begin{array}{l}\overline{22} \\
27 \\
28 \\
34\end{array}$ \\
\hline
\end{tabular}
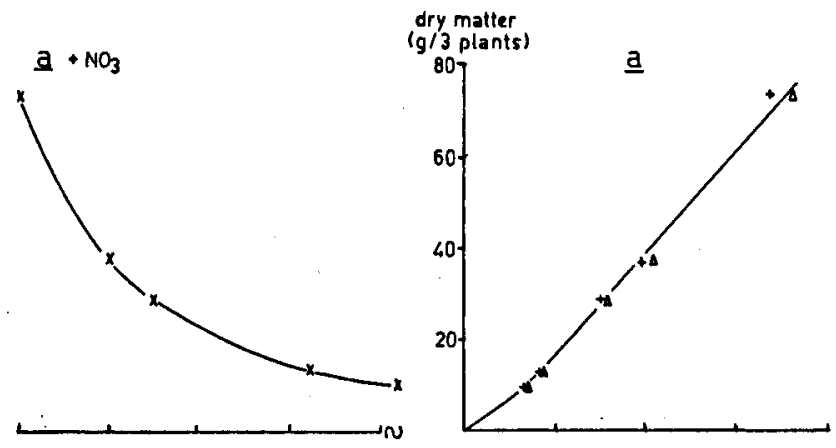

b zero-N
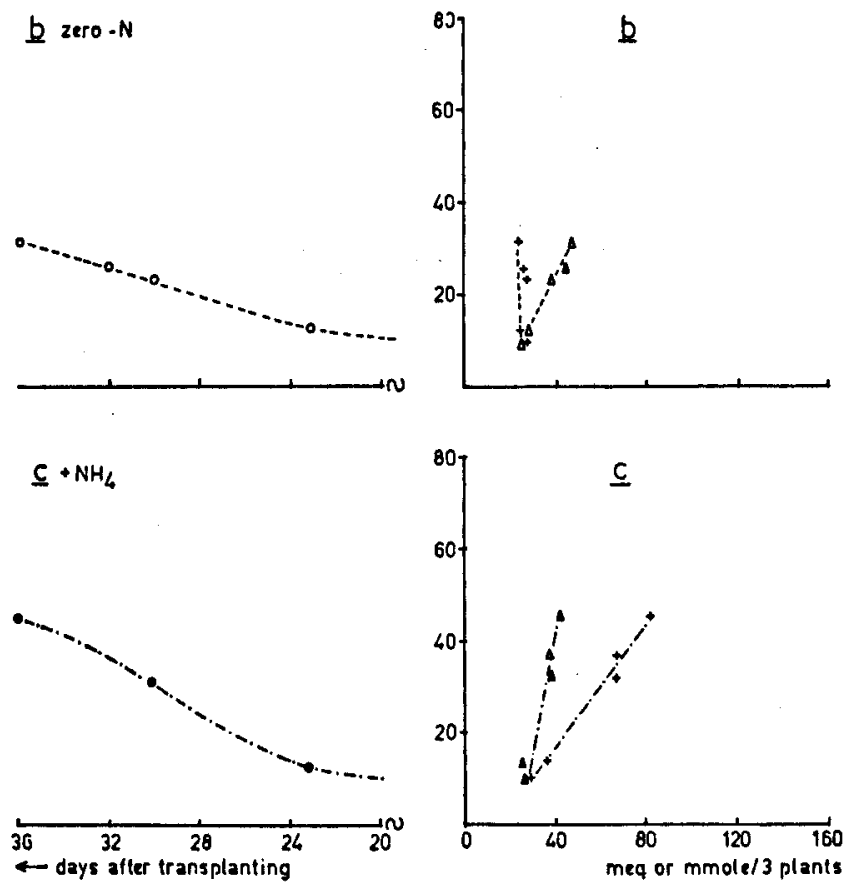

Fig. 2. Production of dry matter, organic $\mathrm{N}$ and $\mathrm{C}-\mathrm{A}$ in sugar-beet plants grown on culture solutions of different nutrient composition.

$\bullet=+\mathrm{NH}_{4} ; \times=+\mathrm{NO}_{3}$;

$0=$ zero-N;

$+=$ organic $\mathrm{N} ; \Delta=(\mathrm{C}-\mathrm{A})$. 
Table 5. Dry matter, (C-A), organic $\mathrm{N}$ and carboxylates per three plants.

\begin{tabular}{lllccc}
\hline $\begin{array}{l}\text { Days after } \\
\text { transplanting }\end{array}$ & Treatment & $\begin{array}{l}\text { Dry matter } \\
(\mathrm{g})\end{array}$ & $\begin{array}{l}\mathrm{C}-\mathrm{A} \\
(\mathrm{meq})\end{array}$ & $\begin{array}{l}\text { Organic N } \\
(\text { mmole) }\end{array}$ & $\begin{array}{l}\text { Carboxylates } \\
(\mathrm{meq})\end{array}$ \\
19 & $+\mathrm{NO}_{3}$ & 10.2 & 27.1 & 27.9 & - \\
23 & $+\mathrm{NO}_{3}$ & 13.7 & 33.7 & 35.2 & - \\
30 & $+\mathrm{NO}_{3}$ & 28.9 & 63.5 & 60.7 & - \\
33 & $+\mathrm{NO}_{3}$ & 37.7 & 83.9 & 78.4 & - \\
36 & $+\mathrm{NO}_{3}$ & 73.7 & 146.1 & 135.4 & - \\
23 & zero-N & 12.7 & 28.7 & 23.7 & - \\
30 & zero-N & 23.4 & 39.0 & 27.7 & - \\
33 & zero-N & 26.1 & 45.8 & 26.1 & - \\
36 & zero-N & 31.6 & 47.6 & 24.4 & - \\
23 & $+\mathrm{NH}_{4}$ & 13.4 & 24.5 & 35.2 & 24.3 \\
30 & $+\mathrm{NH}_{4}$ & 32.0 & 28.0 & 65.7 & 32.6 \\
33 & $+\mathrm{NH}_{4}$ & 36.8 & 37.4 & 67.4 & 33.5 \\
36 & $+\mathrm{NH}_{4}$ & 45.2 & 41.3 & 82.3 & 45.6 \\
\hline
\end{tabular}

* Sometimes meq $\mathrm{NO}_{3}-$ reduced.

tion with nitrate as nitrogen source. In their experiment, the production of carboxylates was equal to the production of organic nitrogen. The data of the nitrate-fed plants of the present trial are in agreement with these results (Table 5 and Fig. 2a).

Plants without nitrogen feeding. On replacing $\mathrm{NO}_{3}-$ in the nutrient solution by $\mathrm{SO}_{4}{ }^{2-}$, there will be no further production of organic nitrogen as soon as the pool of nitrate in the plant is consumed. This is shown by Table 5 and Fig. 2b. However carboxylate production continues (after $\mathrm{NO}_{3}-$ depletion) at a lower rate (Fig. $2 \mathrm{a}$ and 2 b) compared with production of carboxylates by nitrate reduction. The production of carboxylates (after $\mathrm{NO}_{3}-$ was depleted) must be explained with Process 2 of Table 1 . The conclusion that this process is operative is evident from whole plant analysis and from the increase in $\mathrm{H}^{+}$concentration in the nutrient solution during the growth of the plants (Fig. 3).

The change in $\mathrm{pH}$ was so fast that the nutrient solution had to be changed every 30-40 hours. The organic-salt 1 production according to Process 2 takes place in the roots because the exchange of $\mathrm{H}^{+}$ions against other cations absorbed from the nutrient solutions takes place across the root-solution boundary. The carboxylate production resulting from nitrate reduction occurs (to a large extent) in the leaves of the sugar-beet. This conclusion is based on the presence of very high amounts of nitrate ions in the petiole. Assuming that a large part of the oxalates, which constitute about $80 \%$ of the total amount of carboxylates, are not mobile within the plant (van Egmond and Houba, 1970) a change in distribution of the carboxylates is to be expected when Process 2 increases and Process 3 of Table 1 decreases.

The ratio: amount of carboxylates in the shoot to that in the root decreases more in the zero-nitrogen plants than in the nitrate plants (Table 6). The carboxylate content in the roots of the zero-nitrogen plants, however, is lower than in the nitrate

1 Organic salt is used here instead of carboxylate to emphasize that the production of the RCOOcould take place in every plant part but that the salt formation (exchange of $\mathrm{H}+$ towards cations) will take place in the roots. 


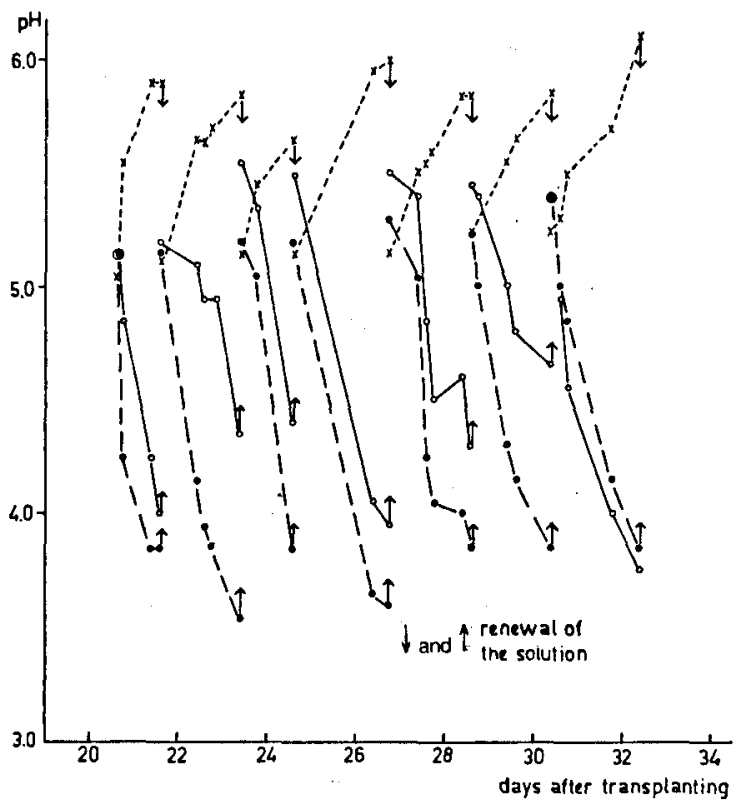

Fig. 3. Variations in $\mathrm{pH}$ of culture solutions caused by sugar-beet plants growing in a solution with nitrate $(x-\cdots x)$, without nitrogen $(0-0)$ and with ammonium (•- $\bullet$ ).

plants (Table 3), because of accumulation of the produced dry matter in the roots of the zero-nitrogen plants.

When carboxylates are considered as an end product of the nitrate reduction, the percentage of carboxylates in dry matter is an interesting figure. Assuming a mean equivalent weight for the carboxylates of $\pm 50 \mathrm{~g}$, the percentage of carboxylates in the dry matter (Table 7 ) of $+\mathrm{NO}_{3}$ plants is about $4 \%$ higher than of the zero-N plants.

Plants fed with ammonium. In this case (Table 5 and Fig. 2c) the production of organic nitrogen per unit dry-matter is almost equal to that of nitrate-fed plants (compare Fig. $2 \mathrm{a}$ and $2 \mathrm{c}$ ). The carboxylate production $(\mathrm{C}-\mathrm{A})$ being equal to carboxylates, Table 5) however falls to a very low rate compared with the other two treatments. This difference in production of $\mathbf{C}-\mathbf{A}$ and organic $\mathbf{N}$ was also shown by Dijkshoorn

Table 6. Ratio of total amounts carboxylates in the shoots to carboxylates in the roots in sugar-beet plants grown with and without nitrate nitrogen in the culture solution.

\begin{tabular}{llr}
\hline $\begin{array}{l}\text { Days after } \\
\text { transplanting }\end{array}$ & \multicolumn{1}{l}{ Treatment } \\
\cline { 2 - 3 } & $+\mathrm{NO}_{3}$ & zero-N \\
19 & 14.1 & 14.1 \\
23 & 17.2 & 8.7 \\
30 & 10.5 & 9.6 \\
33 & 12.8 & 7.7 \\
36 & 10.4 & 5.8 \\
\hline
\end{tabular}


Table 7. Percentage of carboxylates in total dry matter of sugar-beet plants grown on culture solutions with $\mathrm{NO}_{3}$, without nitrogen and with ammonium, respectively.

\begin{tabular}{llll}
\hline $\begin{array}{l}\text { Days after } \\
\text { transplanting }\end{array}$ & \multicolumn{3}{l}{ Treatment } \\
\cline { 2 - 4 } & $+\mathrm{NO}_{3}$ & zero-N & + NH, \\
19 & 13.3 & 13.3 & 13.3 \\
23 & 12.3 & 8.9 & 9.1 \\
30 & 12.0 & 8.4 & 4.4 \\
33 & 12.0 & 8.8 & 5.0 \\
36 & 10.0 & 7.6 & 4.7 \\
\hline
\end{tabular}

et al. (1968) for rye-grass. For the NOs plants the level of carboxylates is 2000 meq, for the zero- $\mathrm{N}$ plants $1000 \mathrm{meq}$ and for the $\mathrm{NH}_{4}$ plants $500 \mathrm{meq} / \mathrm{kg}$ dry matter (these data are calculated from the slopes of the lines in Fig. $2 a, 2 b$ and $2 c$ ). The decrease in $\mathrm{pH}$ in the culture solution during the growth of the plants (Fig. 3) is very pronounced for the ammonium solution. Based on this high $\mathrm{H}^{+}$-exchange one should expect a higher carboxylate production in the ammonium plants than in the plants without nitrogen. The low carboxylate production of only $500 \mathrm{meq} / \mathrm{kg}$ dry matter is associated with the process of $\mathrm{NH}_{4}+$ incorporation into organic nitrogen (Process 5 of Table 1). Due to the low carboxylate production the percentage of carboxylates in the dry-matter (Table 7) is lowest in the ammonium treatment.

\section{Conclusions}

Sugar-beet plants on nutrient solutions of different nitrogen composition can be characterized as follows :

$\mathrm{NO}_{3}$ plants : $\mathrm{C}-\mathrm{A}=$ organic $\mathrm{N}$

zero-N plants : $\mathrm{C}-\mathrm{A}>$ organic $\mathrm{N}$

$\mathrm{NH}_{4}$ plants : $\mathbf{C}-\mathrm{A}<$ organic $\mathrm{N}$

The differences in $\mathrm{H}^{+}$production are in good agreement with the above-mentioned characterization.

\section{Acknowledgment}

We wish to thank Prof. Dr A. C. Schuffelen and Dr W. Dijkshoorn for critical reading of the manuscript.

\section{References}

Dijkshoorn, W., 1962. Metabolic regulation of the alkaline effect of nitrate utilization in plants. Nature 194: 165-167.

Dijkshoorn, W., D. J. Lathwell \& C. T. de Wit, 1968. Temporal changes in carboxylate content of rye-grass with stepwise change in nutrition. Pl. Soil 29: 369-390.

Egmond, F. van \& V. J. G. Houba, 1970. Production of carboxylates (C-A) by young sugar-beet plants grown in nutrient solution, Neth. J. agric. Sci. 18: 182-187.

Ulrich, A., 1942. Metabolism of organic acids in excised barley roots as influenced by temperature, $\mathrm{O}_{z}$ tension and salt concentration. Am. J. Bot, 29: 220-227. 